\title{
Effects of different operating parameters on hydrogen production by Parageobacillus thermoglucosidasius DSM 6285
}

Teresa Mohr', Habibu Aliyu', Lars Biebinger ${ }^{1}$, Roman Gödert ${ }^{1}$, Alexander Hornberger ${ }^{1}$, Don Cowan²,

Pieter de Maayer ${ }^{3}$ and Anke Neumann ${ }^{1 *}$ (D)

\begin{abstract}
Hydrogen gas represents a promising alternative energy source to dwindling fossil fuel reserves, as it carries the highest energy per unit mass and its combustion results in the release of water vapour as only byproduct. The facultatively anaerobic thermophile Parageobacillus thermoglucosidasius is able to produce hydrogen via the water-gas shift reaction catalyzed by a carbon monoxide dehydrogenase-hydrogenase enzyme complex. Here we have evaluated the effects of several operating parameters on hydrogen production, including different growth temperatures, pre-culture ages and inoculum sizes, as well as different pHs and concentrations of nickel and iron in the fermentation medium. All of the tested parameters were observed to have a substantive effect on both hydrogen yield and (specific) production rates. A final experiment incorporating the best scenario for each tested parameter showed a marked increase in the $\mathrm{H}_{2}$ production rate compared to each individual parameter. The optimised parameters serve as a strong basis for improved hydrogen production with a view of commercialisation of this process.
\end{abstract}

Keywords: Parageobacillus thermoglucosidasius, Water-gas shift reaction, Biohydrogen, Process optimization, CO-dehydrogenase

\section{Introduction}

Hydrogen $\left(\mathrm{H}_{2}\right)$ gas is a critical component of diverse industrial applications including the synthesis of ammonia, methanol production and petroleum processing (Ramachandran and Menon 1998). Furthermore, $\mathrm{H}_{2}$ is an efficient energy carrier as, compared to fossil fuel, it has higher energy per unit mass and its combustion produces zero toxic emissions $\left(\mathrm{CO}_{2}, \mathrm{SO}_{2}\right.$ and $\left.\mathrm{NOx}\right)$. Consequently, $\mathrm{H}_{2}$ has been projected as a formidable energy alternative to dwindling fossil fuel reserves and has become an important component of global energy dynamics (Nikolaidis and Poullikkas 2017). Currently, large-scale $\mathrm{H}_{2}$ production is performed via several mechanisms,

\footnotetext{
*Correspondence: anke.neuman@kit.edu

1 Section II: Technical Biology, Institute of Process Engineering in Life Science, Karlsruhe Institute of Technology, 76131 Karlsruhe, Germany Full list of author information is available at the end of the article
}

including natural gas reformation, where carbon atoms from methane separate when exposed to steam and heat, resulting in the release of $\mathrm{H}_{2}$ and carbon monoxide (CO) (Sørensen and Spazzafumo 2011). Other commonly applied approaches include gasification of coal (to $\mathrm{H}_{2}$ and $\mathrm{CO}$ ) and electrolysis of water (to $\mathrm{H}_{2}$ and $\mathrm{O}_{2}$ ). However, these methods are costly, often use fossil fuels and have harmful environmental effects (Nikolaidis and Poullikkas 2017). As such, several biological strategies for hydrogen production have been explored including photofermentation by photosynthetic bacteria, bio-photolysis of water by algae and dark fermentation of organic substances by anaerobic microorganisms (Sokolova et al. 2009). Recently, there has been increased interest in microorganisms that produce $\mathrm{H}_{2}$ via the water-gas shift reaction (WGS): $\mathrm{CO}+\mathrm{H}_{2} \mathrm{O} \rightarrow \mathrm{CO}_{2}+\mathrm{H}_{2}$ (Diender et al. 2015; Mohr et al. 2018a). The WGS reaction couples the oxidation of $\mathrm{CO}$ with the splitting of a water molecule to 
yield $\mathrm{CO}_{2}$ and $\mathrm{H}_{2}$ gas (Tirado-Acevedo et al. 2010). This is particularly pertinent as these microorganisms can use syngas, a natural product of steam reformation of natural gas and gasification of coal and municipal waste, which primarily consists of $\mathrm{CO}, \mathrm{CO}_{2}$ and $\mathrm{H}_{2}$ (Rostrup-Nielsen 1993). The thermophilic bacterium $P$. thermoglucosidasius DSM 6285 produces $\mathrm{H}_{2}$ via the WGS reaction using a carbon monoxide dehydrogenase-NiFe group 4a hydrogenase complex (Mohr et al. 2018b). In contrast to anaerobic organisms, Parageobacillus thermoglucosidasius is a facultative anaerobe which tolerates high concentrations of both $\mathrm{CO}$ and $\mathrm{O}_{2}$, first growing aerobically until $\mathrm{O}_{2}$ is depleted followed by the anaerobic WGS reaction. However, a lag phase was observed between $\mathrm{O}_{2}$ depletion and commencement of $\mathrm{H}_{2}$ production (Mohr et al. $2018 \mathrm{a}, \mathrm{b})$. In the current study the effects of different process parameters on $\mathrm{H}_{2}$ production were investigated in batch experiments. The optimized parameters will form the basis for further development of up-scale biological hydrogen production with $P$. thermoglucosidasius.

\section{Materials and methods}

\section{Microorganism and medium}

Parageobacillus thermoglucosidasius DSM 6285 was obtained from the Deutsche Sammlung von Mikroorganismen und Zellkulturen (DSMZ, Braunschweig, Germany) and stored at $-80{ }^{\circ} \mathrm{C}$ in glycerol (80\%) stocks. The cultivation of $P$. thermoglucosidasius DSM 6285 was performed in 50 mLB (modified Luria-Bertani) medium (Zeigler 2001). This medium contains tryptone $(10 \mathrm{~g} / \mathrm{L})$, yeast extract $(5 \mathrm{~g} / \mathrm{L}), \mathrm{NaCl}(5 \mathrm{~g} / \mathrm{L})$, $1.25 \mathrm{~mL} / \mathrm{L} \mathrm{NaOH}(10 \mathrm{~g} / \mathrm{L})$ and $1 \mathrm{~mL} / \mathrm{L}$ of each of the filter-sterilized stock solutions $1.05 \mathrm{M}$ nitrilotriacetic acid, $0.59 \mathrm{M} \mathrm{MgSO}_{4} \cdot 7 \mathrm{H}_{2} \mathrm{O}, 0.91 \mathrm{M} \mathrm{CaCl}_{2} \cdot 2 \mathrm{H}_{2} \mathrm{O}$ and $0.04 \mathrm{M}$ $\mathrm{FeSO}_{4} \cdot 7 \mathrm{H}_{2} \mathrm{O}$.

\section{Inoculum preparation}

A two-step pre-culture approach was adopted for this study. In the first pre-culture, $20 \mathrm{~mL}$ mLB medium were inoculated with $20 \mu \mathrm{L}$ of glycerol stock and cultivated for $24 \mathrm{~h}$. A second pre-culture was inoculated from the first to an initial absorbance $\left(\mathrm{OD}_{600}\right)$ of 0.1 . All pre-cultures were cultivated aerobically in $100 \mathrm{~mL}$ shake flasks containing $20 \mathrm{~mL} \mathrm{mLB}$ medium at $60^{\circ} \mathrm{C}$ and $120 \mathrm{rpm}$ (Infors Thermotron, Infors AG, Bottmingen, Switzerland). After $12 \mathrm{~h}$, an appropriate amount of the 2nd pre-culture (2\%, $10 \%$ and $20 \% \mathrm{v} / \mathrm{v}$ ) was added to $250 \mathrm{~mL}$ stoppered serum bottles (containing $50 \mathrm{~mL}$ mLB medium total) in an appropriate initial gas atmosphere ratio (36:64, 50:50 and 75:25) of $\mathrm{CO}$ and air at 1 bar atmospheric pressure (at $25^{\circ} \mathrm{C}$ ). Air was required during all set-ups to ensure biomass production prior to the anaerobic $\mathrm{H}_{2}$ production.
The cultivations were performed in triplicate for a duration of $82 \mathrm{~h}$.

\section{Experimental set up}

The effects of different operational parameters on $P$. thermoglucosidasius $\mathrm{H}_{2}$ production were investigated as per Table 1 . To examine the effects of temperature and $\mathrm{pH}$ on growth and hydrogen production, the cultures were maintained at $50{ }^{\circ} \mathrm{C}, 55^{\circ} \mathrm{C}$ and $60{ }^{\circ} \mathrm{C}$. The $\mathrm{pH}$ was adjusted to $5.5,7.0$ and 8.5 using either $\mathrm{NaOH}(1 \mathrm{M})$ or $\mathrm{HCl}(1 \mathrm{M})$. Both the $\mathrm{CODH}$ and group 4a hydrogenase in $P$. thermoglucosidasius are comprised of a $\mathrm{Ni}-\mathrm{Fe}$ metallocenter (Mohr et al. 2018a). To determine the effects of higher iron $\left(\mathrm{Fe}^{2+}\right)$ concentrations on hydrogenogenesis, double the amount of $\mathrm{FeSO}_{4} \cdot 7 \mathrm{H}_{2} \mathrm{O}(0.08 \mathrm{mM})$ normally included in mLB medium $(0.04 \mathrm{mM}$; Mohr et al. 2018a) was added in one experimental set-up. As the $\mathrm{mLB}$ medium does not include the addition of nickel $\left(\mathrm{Ni}^{2+}\right)$, one set-up was prepared containing $0.3 \mathrm{mM}$ $\mathrm{NiSO}_{4} \cdot 6 \mathrm{H}_{2} \mathrm{O}$. The results were compared to those obtained by growing $P$. thermoglucosidasius DSM 6285 in mLB containing only $0.04 \mathrm{mM} \mathrm{FeSO}_{4} \cdot 7 \mathrm{H}_{2} \mathrm{O}$ and no exogenous nickel. The effects of different initial gas compositions on $\mathrm{H}_{2}$ production were also evaluated using 36:64, 50:50 and 75:25 CO:air ratios. The influence of incubation time and volume of the inoculum were studied by varying the incubation times of the 2 nd pre-culture from $4 \mathrm{~h}, 12 \mathrm{~h}$ to $24 \mathrm{~h}$ and by using inoculum volumes of the 2nd pre-culture of $2 \%, 10 \%$ and $20 \%$ of the final volume (50 mL).

To investigate the combination of the parameters which resulted in a superior hydrogen production, a further experiment was conducted. Here, one condition for each parameter was chosen based on the maximum production rate and highest obtained yield: $55{ }^{\circ} \mathrm{C}, \mathrm{pH}$ 7.0 (initial), addition of $\mathrm{FeSO}_{4} \cdot 7 \mathrm{H}_{2} \mathrm{O}(0.08 \mathrm{mM}), 75: 25$ CO:air ratios (initial gas atmosphere), $4 \mathrm{~h}$ incubation time of the 2 nd pre-culture, $10 \%$ inoculum size. To validate whether the tested parameters have a positive effect on the $\mathrm{H}_{2}$ production, the experimental set up as in Mohr

\section{Table 1 Parameters evaluated in the study}

\begin{tabular}{|c|c|c|c|}
\hline Parameter & \multicolumn{3}{|c|}{ Parametric range } \\
\hline Temperature $\left({ }^{\circ} \mathrm{C}\right)$ & 50 & 55 & 60 \\
\hline $\mathrm{pH}$ & 5.5 & 7.0 & 8.5 \\
\hline$\left[\right.$ Nickel] $\left(\mathrm{mM} \mathrm{NiSO}_{4} \cdot 6 \mathrm{H}_{2} \mathrm{O}\right)$ & 0.00 & 0.03 & - \\
\hline$\left[\right.$ Iron] $\left(\mathrm{mM} \mathrm{FeSO}_{4} \cdot 7 \mathrm{H}_{2} \mathrm{O}\right)$ & 0.04 & 0.08 & - \\
\hline $\mathrm{CO}$ air ratio & $36: 64$ & $50: 50$ & $75: 25$ \\
\hline Preculture age $(\mathrm{h})$ & 4 & 12 & 24 \\
\hline Inoculum size $(\mathrm{v} / \mathrm{v} \%)$ & 2 & 10 & 20 \\
\hline
\end{tabular}

Values shaded in grey represent those used in previous experiments (Mohr et al., 2018a, b). Values in bold and green represent those which gave highest $\mathrm{H}_{2}$ productivity and/or $\mathrm{H}_{2}$ yield) 
et al. (2018b) was used as a control: $60^{\circ} \mathrm{C}$ growth temperature, $\mathrm{pH}$ 7.0, $0.04 \mathrm{mM} \mathrm{FeSO} \cdot 7 \mathrm{H}_{2} \mathrm{O}, 50: 50 \mathrm{CO}$ air ratios (initial gas atmosphere), $12 \mathrm{~h}$ incubation time of the $2 \mathrm{nd}$ pre-culture and $2 \%$ inoculum volume.

\section{Analytical methods}

To determine growth, $1 \mathrm{~mL}$ of culture was removed from the bottles through the stoppers using a sterile needle and syringe and absorbance $\left(\mathrm{OD}_{600}\right)$ was measured using an Ultrospec 1100 pro spectrophotometer (Amersham Biosciences, USA). The medium $\mathrm{pH}$ was determined from the same sample using a Profilab pH 597 pH meter (Xylem Analytics Germany Sales GmbH \& Co. KG, WTW, Germany). OD $_{600}$ of 1 equates to $0.3472 \mathrm{~g} / \mathrm{L}$ bio dry weight. To measure the gas compositions at each time point, a $3 \mathrm{~mL}$ gas sample was taken from the headspace of the bottle and injected to a 300 Micro GC gas analyzer (Inficon, Bad Ragaz, Switzerland), fitted with the columns Molsieve and PLOT Q. The column temperature was maintained at $80{ }^{\circ} \mathrm{C}$ for a duration of $180 \mathrm{~s}$. Pressure was measured using a manometer (GDH 14 AN, Greisinger electronic, Regenstauf, Germany) prior to and after each sample was extracted from the bottles.

\section{Data analysis}

Gas compositions were calculated on the basis of the ideal gas law as previously described (Mohr et al. 2018a). In order to compare the results of the different process parameters, hydrogen production rates between different sampling time points were calculated as per Eq. 1:

$$
\text { Production rate }=\frac{\Delta m_{\text {hydrogen }}[\mathrm{mmol}]}{\Delta \text { time }[\mathrm{h}]} .
$$

The specific production rate was calculated as per Eq. 2:

$$
\text { Specific production rate }=\frac{\Delta m_{\text {hydrogen }}[\mathrm{mmol}]}{\Delta \text { time }[\mathrm{h}] * O D_{600}} .
$$

The overall $\mathrm{H}_{2}$ yield for each of the experiments was calculated as a function of $\mathrm{CO}$ consumption (Eq. 3). This was done for the hydrogenogenic phase from the first time point where $\mathrm{H}_{2}$ was detected (24 h post-inoculation) until the $\mathrm{CO}$ was consumed in most experimental set-ups (72 $\mathrm{h}$ post-inoculation).

$$
\text { Yield }=\frac{\Delta \mathrm{H} 2[\mathrm{mmol}]}{\Delta \mathrm{CO}[\mathrm{mmol}]} .
$$

\section{Results \\ Effect of initial gas composition on $\mathrm{H}_{2}$ productivity}

To evaluate the effect of the initial gas composition, $\mathrm{H}_{2}$ production with three distinct CO:air ratios (36:64, 50:50 and 75:25) was determined. Spectrophotometric analysis of the biomass showed that, while $P$. thermoglucosidasius DSM 6285 grown in the 36:64 and 50:50 CO:air gas ratios grew to a maximum absorbance of $0.744 \pm 0.103$ (after $24 \mathrm{~h}$ ) and $0.620 \pm 0.137$ (after $24 \mathrm{~h}$ ), respectively, it grew substantially less and at a slower rate with a 75:25 CO:air ratio, with a maximum absorbance of $0.476 \pm 0.028$ after $72 \mathrm{~h}$ (Fig. 1, Additional file 1). This suggests that the lower $\mathrm{O}_{2}$ concentration affected effective biomass formation in the initial aerobic phase. $\mathrm{O}_{2}$ reached its minimum for all tested gas compositions after $\sim 24 \mathrm{~h}$, while $\mathrm{H}_{2}$ was initially detected at approximately the same time. $\mathrm{CO}$ was completely consumed at the end of the cultivations in all instances (Fig. 2a). Maximum $\mathrm{H}_{2}$ production rates were observed between the $34 \mathrm{~h}$ and $48 \mathrm{~h}$ sample points in all cases. The highest values were observed for P. thermoglucosidasius exposed to the $75: 25 \%$ atmosphere, with $0.138 \pm 0.009 \mathrm{mmol} / \mathrm{h} \mathrm{H}_{2}$ produced in this time frame. By contrast, substantially lower maximum production rates were observed with $36 \%$ and $50 \% \mathrm{CO}$ in the initial gas atmosphere $(0.073 \pm 0.006 \mathrm{mmol} / \mathrm{h}$ and $0.094 \pm 0.016 \mathrm{mmol} / \mathrm{h}$, respectively) (Table 2 ). With an increasing initial $\mathrm{CO}$ concentration, the specific productivity increases from $0.104 \pm 0.016(36 \%$ CO), $0.163 \pm 0.054 \quad(50 \% \quad C O)$ to $0.351 \pm 0.038 \quad(75 \%$ $\mathrm{CO})$. The overall $\mathrm{H}_{2}$ yield during the hydrogenogenic phase was also higher with the $75 \% \mathrm{CO}$ concentration $\left(0.807 \pm 0.022 \mathrm{mmol} \mathrm{H}_{2} / \mathrm{mmol} \mathrm{CO}\right)$ than when $50 \%$ and $36 \%$ CO were present in the bottles $(5.45$ and $7.31 \%$ higher, respectively) (Table 2).

\section{Effect of inoculum preparation on $\mathrm{H}_{2}$ productivity}

The effect of different inoculum preparations on $\mathrm{H}_{2}$ production by $P$. thermoglucosidasius DSM 6285 was determined using different inoculum sizes $(2 \%, 10 \%, 20 \%$ $\mathrm{v} / \mathrm{v})$ and incubation times of the 2nd pre-cultures $(4 \mathrm{~h}$, $12 \mathrm{~h}, 24 \mathrm{~h}$ ). Maximum $\mathrm{OD}_{600}$ was observed after $\sim 72$ and $24 \mathrm{~h}$ when inocula (incubated for $12 \mathrm{~h}$ ) of $2 \%$ $\left(\mathrm{OD}_{600}=0.620 \pm 0.137\right)$ and $10 \%\left(\mathrm{OD}_{600}=0.923 \pm 0.054\right)$ were added, respectively (Fig. 1, Additional file 2). The highest $\mathrm{OD}_{600}$ was observed when the highest cell concentration $(20 \%)$ was added, with a maximum absorbance of $1.057 \pm 0.063 \sim 7 \mathrm{~h}$ post-inoculation (Additional file 2). However, during the aerobic growth phase the highest growth rate was observed for the $2 \%$ inoculum $(0.141 / \mathrm{h})$ (Table 2). Oxygen reached its minimal plateau $\sim 24 \mathrm{~h}$ post-inoculation for all three inoculum sizes, and $\mathrm{H}_{2}$ was first detected at this time when a $10 \%$ inoculum $(0.021 \pm 0.010 \mathrm{mmol})$ and $20 \%$ inoculum $(0.024 \pm 0.015 \mathrm{mmol})$ was used (Fig. 2b). By contrast, with the $2 \%$ inoculum, $0.009 \pm 0.003 \mathrm{mmol}$ of $\mathrm{H}_{2}$ could already be detected $\sim 12 \mathrm{~h}$ after inoculation and $0.103 \pm 0.027 \mathrm{mmol}$ was detected after $24 \mathrm{~h}$. CO 


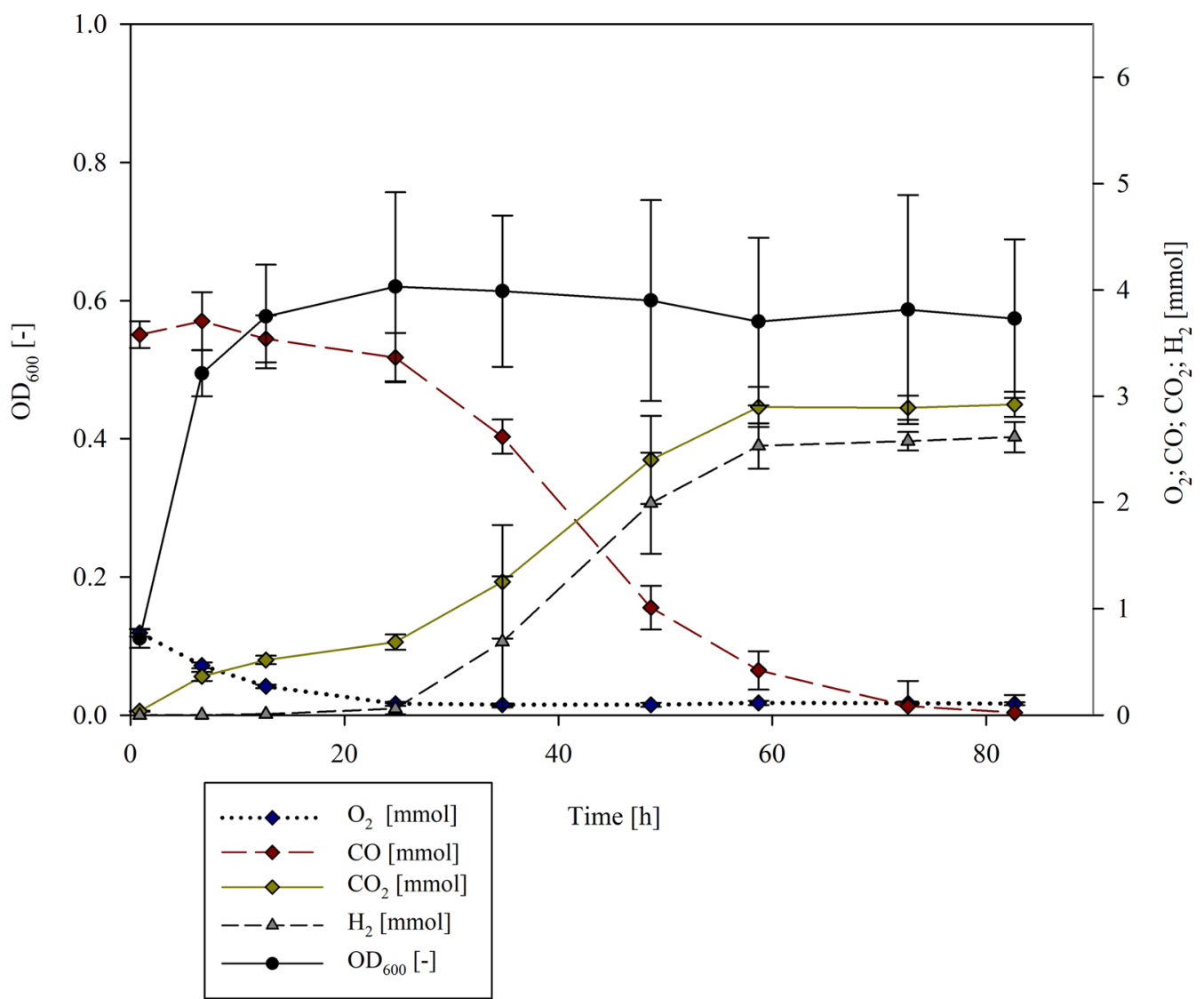

Fig. 1 Growth curve and gas composition during the cultivation of $P$. thermoglucosidasius DSM 6285 in the control set up $\left(60^{\circ} \mathrm{C}, \mathrm{pH} 7.0\right.$, addition of $0.04 \mathrm{mM} \mathrm{FeSO}_{4} \cdot 7 \mathrm{H}_{2} \mathrm{O}, 50: 50$ initial gas atmosphere $\mathrm{CO}$ air ratios, $12 \mathrm{~h}$ incubation time of the 2 nd pre-culture, $2 \%$ inoculum size)

was mostly depleted after $\sim 83 \mathrm{~h}(10 \%$ inoculum, $2 \%$ inoculum), while $0.179 \pm 0.239 \mathrm{mmol} \mathrm{CO}$ was still present at this time point with the $20 \%$ inoculum (Fig. 2b). When considering hydrogen production rate, the highest production rate was observed with the $10 \%$ inoculum $(0.101 \pm 0.022 \mathrm{mmol} / \mathrm{h})$, and occurred between 25 and $35 \mathrm{~h}$ post-inoculation (Table 2). A slightly lower maximum production rate $(0.094 \pm 0.016 \mathrm{mmol} / \mathrm{h})$ was seen with the $2 \%$ inoculum and occurred later (between $35-48 \mathrm{~h}$ post-inoculation) than with the $10 \%$ inoculum. Maximum production rate for the highest inoculum size (20\%) was achieved only between the 59-73 h time intervals and was $48.52 \%$ and $38.24 \%$ less than was observed with the $10 \%$ and $2 \%$ inocula, respectively (Table 2 ). Though the specific production rate was the highest for the $2 \%$ inoculum $\left(0.14 \mathrm{mmol} / \mathrm{h} / \mathrm{OD}_{600}\right)$, the overall $\mathrm{H}_{2}$ yield is highest for the $10 \%$ inoculum (Table 2), and this inoculum size was thus selected as the optimal parameter for further experiments.

Substantial differences in the growth, maximum production rates and $\mathrm{H}_{2}$ yields could also be observed when distinct pre-culture inocula ages were evaluated.
For the $4 \mathrm{~h}$ pre-culture, it took $\sim 12 \mathrm{~h}$ to reach its maximum absorbance $\left(\mathrm{OD}_{600}=0.50 \pm 0.01\right)$, while it took $\sim 24 \mathrm{~h}$ for the $12 \mathrm{~h}(0.620 \pm 0.137)$ and $24 \mathrm{~h}$ inocula $(0.56 \pm 0.124)$ to reach their maximum absorbances (Fig. 1, Additional file 3). Growth rates during the aerobic phase also differed. Cultures inoculated with a 2nd pre-culture cultivated for $4 \mathrm{~h}$, showed the highest growth rate $(0.3271 / \mathrm{h})$ (Table 2). While in all cases maximum production rate occurred between the same time points, $36-48 \mathrm{~h}$ post-inoculation, the maximal production rate and $\mathrm{H}_{2}$ yield were highest with the $4 \mathrm{~h}$ preinoculum $(0.129 \pm 0.018 \mathrm{mmol} / \mathrm{h}$ between 35 and $49 \mathrm{~h}$; $0.796 \pm 0.029 \mathrm{mmol} \mathrm{H}_{2} / \mathrm{mmol} \mathrm{CO}$ ). The same pattern was observed for the specific production rate (Fig. 2c, Table 2).

\section{Effect of $\mathrm{pH}$ and temperature on hydrogen production}

Different medium pHs $(5.5,7.0,8.5)$ and cultivation temperatures $\left(50{ }^{\circ} \mathrm{C}, 55{ }^{\circ} \mathrm{C}, 60{ }^{\circ} \mathrm{C}\right)$ were evaluated for their effects on hydrogen production. The maximum $\mathrm{OD}_{600}$ was observed in cultures maintained at $55{ }^{\circ} \mathrm{C}$ (maximum $\mathrm{OD}_{600}=0.854 \pm 0.141$ after $48 \mathrm{~h} ; \mathrm{OD}_{600}=0.846 \pm 0.118$ 

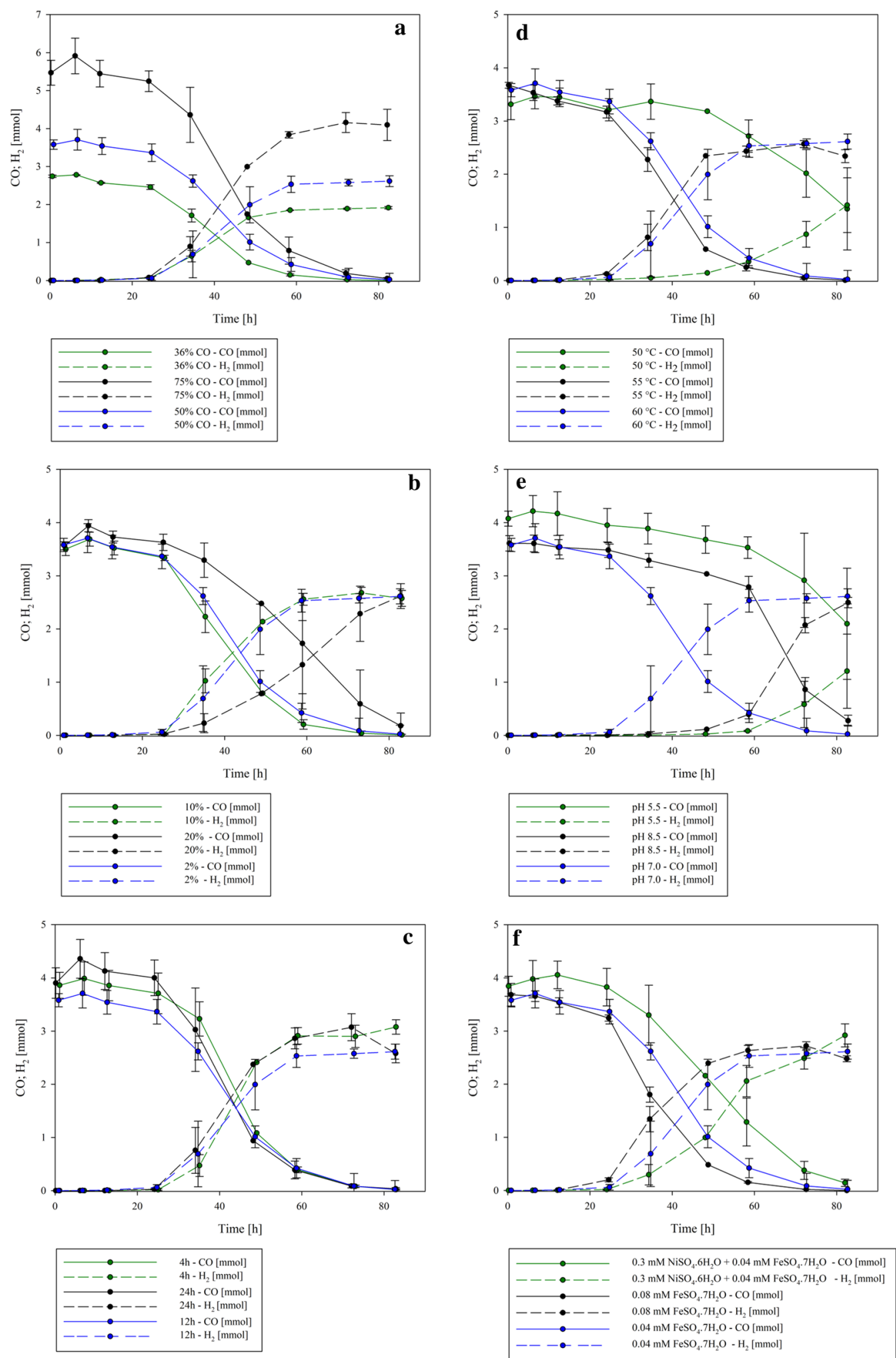

Fig. 2 Effects of several operating parameters on $\mathrm{CO}$ consumption and $\mathrm{H}_{2}$ production during the cultivation of $P$. thermoglucosidasius. a Initial gas composition, $\mathbf{b}$ inoculum size, $\mathbf{c}$ age of 2 nd pre-culture, $\mathbf{d}$ temperature, $\mathbf{e}$ initial $\mathrm{pH}$ and $\mathbf{f}$ addition of $\mathrm{FeSO}_{4} \cdot 7 \mathrm{H}_{2} \mathrm{O}$ and $\mathrm{NiSO}_{4} \cdot 6 \mathrm{H}_{2} \mathrm{O}$ 
Table 2 Hydrogen production rate $(\mathrm{mmol} / \mathrm{h})$, specific production rate $\left(\mathrm{mmol} / \mathrm{h} / \mathrm{OD}_{600}\right)$, yield $\left(\mathrm{H}_{2} \mathrm{mmol} / \mathrm{CO} \mathrm{mmol}\right)$ and growth rates for the individual and combined parameters

\begin{tabular}{|c|c|c|c|c|c|c|c|}
\hline \multirow[t]{2}{*}{ Parameter } & \multicolumn{2}{|l|}{ Production rate } & \multicolumn{2}{|c|}{ Specific production rate } & \multirow{2}{*}{$\begin{array}{l}\text { Yield }^{\mathrm{a}}\left(\mathrm{H}_{2}\right. \\
\mathrm{mmol} / \mathrm{CO} \\
\mathrm{mmol})\end{array}$} & \multicolumn{2}{|c|}{ Aerobic growth phase } \\
\hline & Maximum $(\mathrm{mmol} / \mathrm{h})$ & Time (h) & $\begin{array}{l}\text { Maximum } \\
\left(\mathrm{mmol} / \mathrm{h} * \mathrm{OD}_{600}\right)\end{array}$ & Time (h) & & $\Delta O D_{600}(t 12-t 0)$ & $\mu(1 / h)$ \\
\hline $\begin{array}{l}\text { Control: } 60^{\circ} \mathrm{C} ; \mathrm{pH} 7.0 ; 0.04 \mathrm{mM} \mathrm{Fe}^{2+} ; \\
\text { no } \mathrm{Ni}^{2+} ; 50 \% \mathrm{CO} ; 12 \text { h pre-culture; } \\
2 \% \text { inoculum }\end{array}$ & $0.094 \pm 0.016$ & $35-48$ & $0.163 \pm 0.054$ & $35-48$ & $0.763 \pm 0.026$ & $0.467 \pm 0.073$ & 0.14 \\
\hline $50^{\circ} \mathrm{C}$ & $0.055 \pm 0.027$ & $73-82$ & $0.144 \pm 0.06$ & $73-82$ & $0.698 \pm 0.068$ & $0.647 \pm 0.044$ & 0.163 \\
\hline $55^{\circ} \mathrm{C}$ & $0.098 \pm 0.006$ & $34-48$ & $0.124 \pm 0.001$ & $34-48$ & $0.783 \pm 0.014$ & $0.716 \pm 0.059$ & 0.172 \\
\hline pH 5.5 & $0.06 \pm 0.025$ & $72-82$ & $0.358 \pm 0.103$ & $72-82$ & $0.606 \pm 0.168$ & $0.127 \pm 0.035$ & 0.128 \\
\hline $\mathrm{pH} 8.5$ & $0.122 \pm 0.005$ & $59-72$ & $0.294 \pm 0.028$ & $59-72$ & $0.786 \pm 0.018$ & $0.348 \pm 0.006$ & 0.127 \\
\hline $\begin{array}{l}0.3 \mathrm{mM} \mathrm{NiSO}_{4} \cdot 6 \mathrm{H}_{2} \mathrm{O}+0.04 \mathrm{mM} \\
\mathrm{FeSO} 4 \cdot 7 \mathrm{H}_{2} \mathrm{O}\end{array}$ & $0.078 \pm 0.015$ & $48-58$ & $0.192 \pm 0.035$ & $48-58$ & $0.716 \pm 0.032$ & $0.36 \pm 0.056$ & 0.122 \\
\hline $0.08 \mathrm{mM} \mathrm{FeSO}_{4} \cdot 7 \mathrm{H}_{2} \mathrm{O}$ & $0.115 \pm 0.020$ & $25-35$ & $0.24 \pm 0.052$ & $25-35$ & $0.782 \pm 0.012$ & $0.442 \pm 0.052$ & 0.127 \\
\hline 36:64 CO:air & $0.073 \pm 0.006$ & $34-48$ & $0.104 \pm 0.016$ & $34-48$ & $0.748 \pm 0.006$ & $0.256 \pm 0.042$ & 0.095 \\
\hline 75:25 CO:air & $0.138 \pm 0.009$ & $34-48$ & $0.351 \pm 0.038$ & $34-48$ & $0.807 \pm 0.022$ & $0.136 \pm 0.083$ & 0.064 \\
\hline $4 \mathrm{~h}$ pre-culture & $0.129 \pm 0.018$ & $35-49$ & $0.303 \pm 0.046$ & $35-49$ & $0.796 \pm 0.029$ & $0.491 \pm 0.015$ & 0.372 \\
\hline $24 \mathrm{~h}$ pre-culture & $0.115 \pm 0.025$ & $34-48$ & $0.27 \pm 0.098$ & $34-48$ & $0.779 \pm 0.013$ & $0.316 \pm 0.027$ & 0.132 \\
\hline $10 \%$ inoculum & $0.101 \pm 0.022$ & $25-35$ & $0.137 \pm 0.025$ & $25-35$ & $0.806 \pm 0.025$ & $0.425 \pm 0.063$ & 0.052 \\
\hline $20 \%$ inoculum & $0.068 \pm 0.023$ & $59-73$ & $0.108 \pm 0.029$ & $59-73$ & $0.741 \pm 0.028$ & $0.151 \pm 0.131$ & 0.013 \\
\hline $\begin{array}{l}\text { Combined: } 55^{\circ} \mathrm{C}, \mathrm{pH} 7.0,0.08 \mathrm{mM} \\
\mathrm{Fe}^{2+}, \text { no } \mathrm{Ni}^{2+}, 75 \% \mathrm{CO} ; 4 \text { h pre- } \\
\text { culture; } 10 \% \text { inoculum }\end{array}$ & $0.182 \pm 0.009$ & $34-58$ & $0.566 \pm 0.024$ & $34-58$ & $0.808 \pm 0.01$ & $0.323 \pm 0.02$ & 0.32 \\
\hline
\end{tabular}

a Calculated between $24 \mathrm{~h}$ and $72 \mathrm{~h}$ cultivation time

after $24 \mathrm{~h}$ ), followed by growth at $50{ }^{\circ} \mathrm{C}$ (maximum $\mathrm{OD}_{600}=0.787 \pm 0.039$ after $24 \mathrm{~h}$ ) and $60{ }^{\circ} \mathrm{C}$ (maximum $\mathrm{OD}_{600}=0.620 \pm 0.137$ after $24 \mathrm{~h}$ ) (Fig. 1, Additional file 4). During aerobic growth, the growth rate during the cultivation at $55^{\circ} \mathrm{C}$ was highest $(0.1721 / \mathrm{h})$, followed by $50{ }^{\circ} \mathrm{C}(0.1631 / \mathrm{h})$ and $60{ }^{\circ} \mathrm{C}(0.140 \mathrm{1} / \mathrm{h})$ (Table 2). Depletion of $\mathrm{O}_{2}(\sim 24 \mathrm{~h})$ and $\mathrm{CO}$ (after $\sim 72 \mathrm{~h}$ ) occurred earlier at $55^{\circ} \mathrm{C}$ and $60^{\circ} \mathrm{C}$ than at $50^{\circ} \mathrm{C}\left(\mathrm{O}_{2}\right.$ depletion after $\sim 36 \mathrm{~h}$; $1.346 \pm 0.772 \mathrm{mmol} \mathrm{CO}$ after $72 \mathrm{~h}$ ) (Fig. 2d, Additional file 4). This correlated with both the higher maximum $\mathrm{H}_{2}$ production rates and yields observed at the higher temperatures. Highest production rates at these temperatures occurred between 34 and $48 \mathrm{~h}$ post-inoculation, while at $50{ }^{\circ} \mathrm{C}$ this was only achieved in the last part (73$82 \mathrm{~h}$ ) of the experiment (Fig. 2d). Only marginal differences in both maximum production rates and yield were observed with the other experimental temperatures, with both factors being slightly higher $\left(0.004 \mathrm{mmol} / \mathrm{h}\right.$ more $\mathrm{H}_{2}$ produced between 34 and $48 \mathrm{~h}$; yield: $0.085 \mathrm{mmol}$ more $\mathrm{H}_{2}$ per mmol CO) at $55^{\circ} \mathrm{C}$ than at $60{ }^{\circ} \mathrm{C}$ (Table 2). Given these marginal differences and the superior growth rate at $55{ }^{\circ} \mathrm{C}$, this temperature was selected as the optimal condition for further experimentation although the specific production rate was the lowest during the cultivation at $55^{\circ} \mathrm{C}$.
More substantial differences could be observed for P. thermoglucosidasius grown in media adjusted prior inoculation to $\mathrm{pH}$ 5.5, 7.0 and 8.5. The highest $\mathrm{OD}_{600}$ was observed for the pH 7.0 cultures (maximum absorbance of $0.620 \pm 0.137$ after $\sim 24 \mathrm{~h}$ ), while $P$. thermoglucosidasius grew least well at $\mathrm{pH} 8.5$ (maximum absorbance of $0.463 \pm 0.018$ after $6 \mathrm{~h}$ ) (Additional file 5 ). The growth rate (aerobic phase) during the cultivation with a $\mathrm{pH}$ of 7.0 was also higher than with the other two medium pHs. Differences in oxygen consumption were also observed. Whereas $\mathrm{O}_{2}$ reached its minimal plateau after $\sim 24 \mathrm{~h}$ for the cultivations with medium $\mathrm{pH} 7.0$ and 8.5 , it only reached its minimum after $48 \mathrm{~h}$ at $\mathrm{pH} 5.5$ (Fig. 1, Additional file 5). The highest maximal $\mathrm{H}_{2}$ production rate $(0.122 \pm 0.005 \mathrm{mmol} / \mathrm{h})$ and yield $(0.786 \pm 0.018 \mathrm{mmol}$ $\mathrm{H}_{2} / \mathrm{mmol} \mathrm{CO}$ ) were observed at $\mathrm{pH}$ 8.5. However, maximum productivity occurred substantially later (59-72 h post-inoculation) when a medium $\mathrm{pH}$ of 7.0 was used (35-48 h post-inoculation) (Fig. 2e, Additional file 5). By contrast, the specific production rate was higher at $\mathrm{pH}$ 5.5 and $\mathrm{pH} 8.5$ than at $\mathrm{pH} 7.0$, but occurred $12-24 \mathrm{~h}$ later. As the concept of parametric optimization should not be considered solely on the basis of yield, but also the timeefficiency of the process, the $\mathrm{pH}$ of 7.0 was selected as the optimum condition for $\mathrm{H}_{2}$ production. 
Effect of nickel and iron concentration on $\mathrm{H}_{\mathbf{2}}$ production Both the carbon monoxide dehydrogenase (CODH) and the hydrogenase that catalyses the WGS contain nickel $\left(\mathrm{Ni}^{2+}\right)$ and iron $\left(\mathrm{Fe}^{2+}\right)$ as co-factors (Can et al. 2014; Peters et al. 2015; Mohr et al. 2018a). Exogenous nickel and iron were added to the medium in order to evaluate their effect on hydrogenogenesis. The addition of nickel resulted in a maximal absorbance $\left(\mathrm{OD}_{600}\right)$ of $0.486 \pm 0.022$ after $24 \mathrm{~h}$. When more iron was added, the $\mathrm{OD}_{600}$ rose to a maximum of $0.572 \pm 0.066$ after $12 \mathrm{~h}$ (Additional file 6). By contrast, the control fermentation (no additional nickel or iron) showed a higher maximum absorbance of $0.620 \pm 0.137$ after $24 \mathrm{~h}$ (Additional file 6). However, the aerobic growth rate was less if no extra nickel or more iron was added. In all set-ups oxygen attained its minimum after $\sim 24 \mathrm{~h}$. Hydrogen was detected for the first time after $\sim 12 \mathrm{~h}$ without added iron $(0.009 \pm 0.003 \mathrm{mmol})$ and after $24 \mathrm{~h}$ with additional iron $(0.199 \pm 0.038 \mathrm{mmol})$, while when nickel was added $\mathrm{H}_{2}$ production only commenced after $24 \mathrm{~h}$ $(0.017 \pm 0.012 \mathrm{mmol})$. CO was completely consumed after $82 \mathrm{~h}$ when iron was added and in the control samples, whereas $0.144 \pm 0.069 \mathrm{mmol}$ was still available when nickel was added (Fig. 2f). The addition of nickel also resulted in a substantially lower maximal production rate ( $0.078 \mathrm{mmol} / \mathrm{h}$ between 48 and $60 \mathrm{~h}$ post-inoculation), which was $17.02 \%$ less than was achieved without addition of nickel and iron, 36-48 h post-inoculation. By contrast, addition of iron resulted in a higher maximum production rate $(0.115 \mathrm{mmol} / \mathrm{h})$, which occurred $12 \mathrm{~h}$ earlier than the without the addition of iron. Furthermore, the overall yield was $\sim 2 \%$ and $8 \%$ higher with the addition of iron than when nickel was added or when no nickel or added iron were included (Table 2). Therefore, the addition of $0.08 \mathrm{mM} \mathrm{FeSO} \cdot 7 \mathrm{H}_{2} \mathrm{O}$ was selected for subsequent experiments.

\section{Optimized hydrogen production}

From the experiments evaluating the individual parameters, all tested parameters were observed to have substantial effects on both hydrogen yield and maximum production rates. In a further experiment, the effects of a combination of the optimum parameters $\left(55^{\circ} \mathrm{C}, \mathrm{pH}\right.$ 7.0, addition of $\mathrm{FeSO}_{4} \cdot 7 \mathrm{H}_{2} \mathrm{O}(0.08 \mathrm{mM})$, 75:25 CO:air ratios (initial gas atmosphere), $4 \mathrm{~h}$ incubation time of the 2 nd pre-culture, $10 \%$ inoculum size) on hydrogenogenesis was established. In this experiment, $P$. thermoglucosidasius growth to a maximum absorbance was observed after $\sim 48 \mathrm{~h}\left(\mathrm{OD}_{600}=0.388 \pm 0.018\right)$, while $\mathrm{O}_{2}$ was depleted earlier (after $\sim 24 \mathrm{~h}$ ). At this time, $\mathrm{H}_{2}$ was detected for the first time $(0.071 \pm 0.02 \mathrm{mmol})$ (Fig. 3).

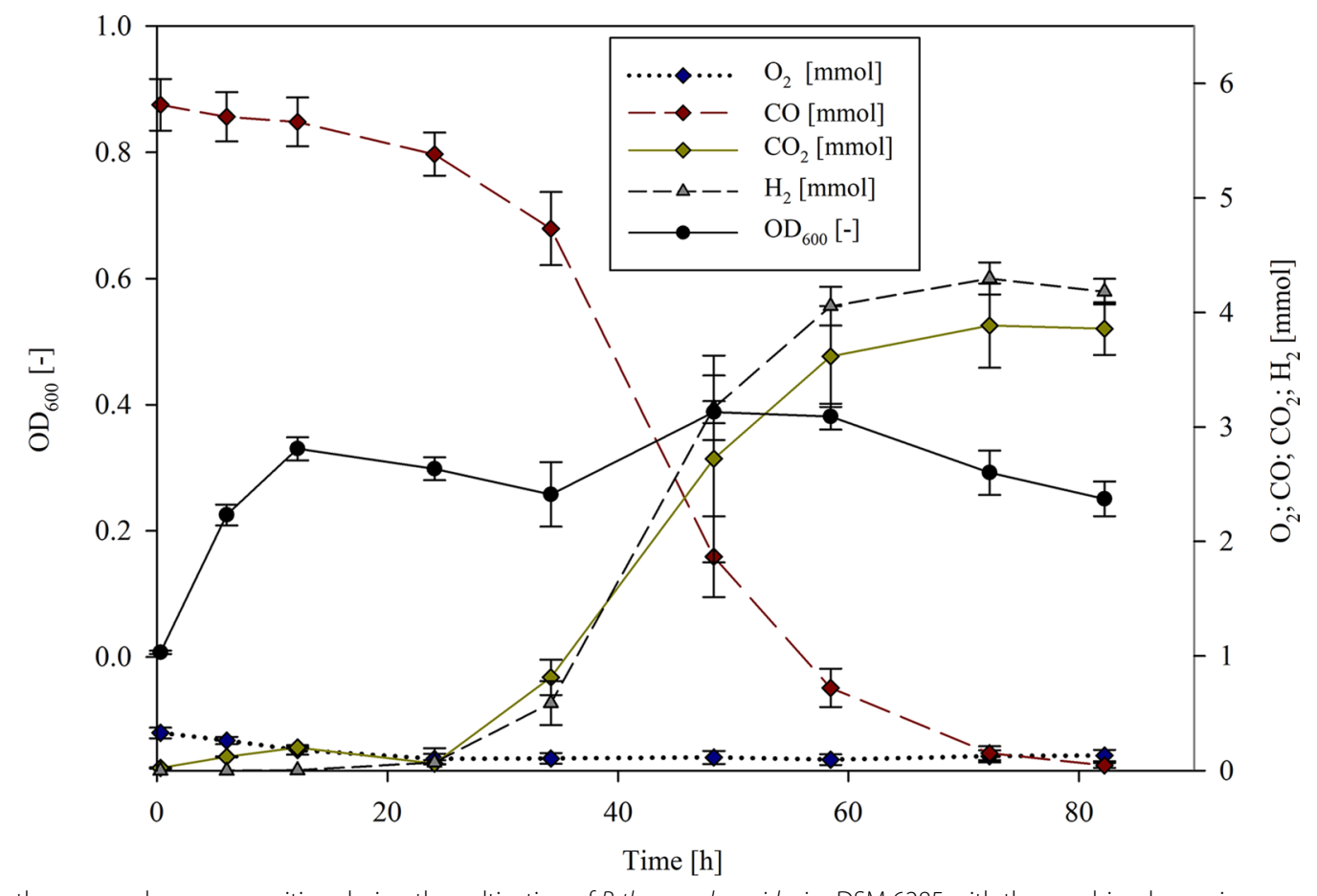

Fig. 3 Growth curve and gas composition during the cultivation of $P$. thermoglucosidasius DSM 6285 with the combined superior parameters $\left(55^{\circ} \mathrm{C}, \mathrm{pH} 7.0\right.$, addition of $0.08 \mathrm{mM} \mathrm{FeSO}_{4} \cdot 7 \mathrm{H}_{2} \mathrm{O}, 75: 25$ initial gas atmosphere $\mathrm{CO}$ :air ratios, $4 \mathrm{~h}$ incubation time of the $2 \mathrm{nd}$ pre-culture, $10 \%$ inoculum size) 
Comparison to the previously evaluated control set-up $\left(60{ }^{\circ} \mathrm{C}, \mathrm{pH} 7.0,0.04 \mathrm{mM} \mathrm{FeSO}_{4} \cdot 7 \mathrm{H}_{2} \mathrm{O}, 50: 50 \mathrm{CO}\right.$ :air ratio, $12 \mathrm{~h}$ incubation time of the 2 nd pre-culture, $2 \%$ inoculum size; Mohr et al. 2018b) showed a modest increase in $\mathrm{H}_{2}$ yield ( $2 \%$ higher) when the optimized conditions were used (Table 2). However, marked increases in both the maximum $\left(1.9 \times\right.$ higher) and specific $\mathrm{H}_{2}$ production rate $(3.5 \times$ higher) could be observed with the optimized parameters, occurring $\sim 35-48 \mathrm{~h}$ post-inoculation in both cases. These factors were also substantially higher than each of the single tested parameters, with a $1.6 \times$ and $5.4 \times$ fold increase in specific $\mathrm{H}_{2}$ production rate for the best (75:25 CO:air ratio) and worst (36:64 CO:air ratio) performing individual parameter, respectively (Table 2).

\section{Discussion}

A critical aspect of microbial fermentations that involve gas as the main substrate or $\mathrm{e}^{-}$acceptor is the solubility of the gas and the threshold concentration that does not inhibit the metabolism of the microorganisms (Bertsch and Müller 2015). In general, high gas concentrations can have an inhibitory effect while low gas concentrations can result in a low volumetric mass transfer coefficient resulting in limited substrate availability (Daniell et al. 2012; Mohammadi et al. 2014). This was evident in the fermentations with $P$. thermoglucosidasius DSM 6285 as less growth (biomass) was observed with increasing $\mathrm{CO}$ concentrations and concomitantly lower concentration of oxygen as terminal electron acceptor during the aerobic growth phase. However, poorer growth at higher $\mathrm{CO}$ concentrations did not have a negative effect on the hydrogenogenic capacity of $P$. thermoglucosidasius DSM 6285 , with the highest $\mathrm{H}_{2}$ production rate observed with the $75: 25 \%$ CO:air mixture. The higher production rate with $75 \% \mathrm{CO}$, which grew to the lowest optical density, suggests that hydrogen productivity is a function of the availability of $\mathrm{CO}$, rather than being dependent on the amount of biomass. To investigate the influence of the amount of biomass prior the hydrogen production phase, cultivations in bottles were undertaken using different inoculum sizes.

The size and age of inocula can have substantial effects on hydrogen fermentations, as has been observed in the fermentative thermophile Thermoanaerobacterium thermosaccharolyticum and the photosynthetic purple nonsulphur bacterium Rhodobacter sphaeroides (Japaar et al. 2011; Seengenyoung et al. 2011). The highest production rate was detected with the $10 \%$ inoculum size, while the lowest production rate was achieved with the highest inoculum size (20\%). Similar results were obtained with the fermentative $\mathrm{H}_{2}$-producer Bacillus coagulans IITBT S1, where higher $\mathrm{H}_{2}$ production rates were observed with a $10 \%$ inoculum volume, but decreased with larger
(15\% and 20\%) inoculum sizes (Kotay and Das 2007). As such, $\mathrm{H}_{2}$ production appears not to be directly linked to the amount of biomass but may rather be a function of the physiological state of $P$. thermoglucosidasius. To confirm this hypothesis, different cultivation times $(4 \mathrm{~h}$, $12 \mathrm{~h}, 24 \mathrm{~h}$ ) of the 2nd pre-culture were tested. Although the maximum production rate was detected at the same time points, $\mathrm{H}_{2}$ production with the shortest incubation time of the 2nd pre-culture $(4 \mathrm{~h})$ showed the highest production rate. The $4 \mathrm{~h}$ pre-cultures may be in the lag growth phase preceding exponential growth (12-24 h), the preparative phase where bacteria adapt optimally to new environments (i.e., the exposure of $P$. thermoglucosidasius to CO) (Bertrand 2019). This pre-adaptive physiological state may explain the highest production rate observed with the $4 \mathrm{~h}$ pre-culture. Similarly, the lower $\mathrm{H}_{2}$ production rates with the $20 \%$ inoculum size may be due to the cells reaching the post-lag exponential phase more rapidly than the optimal $10 \%$ inoculum size.

Parageobacillus thermoglucosidasius strains grow optimally at temperatures of $61-63{ }^{\circ} \mathrm{C}$ and an initial medium $\mathrm{pH}$ of 6.5-8.5 (Suzuki et al. 1984). The strain utilized in this study, DSM 6285, is reported to grow optimally at $55^{\circ} \mathrm{C}$, with some growth at $75^{\circ} \mathrm{C}$ (Gurujeyalakshmi and Oriel 1989). In the current study, a growth temperature of $55{ }^{\circ} \mathrm{C}$ and a medium $\mathrm{pH}$ of 7.0 resulted in optimal $\mathrm{H}_{2}$ production. Although the highest $\mathrm{H}_{2}$ production rate was obtained with the $\mathrm{pH}=8.5$ set up, the lag phase between oxygen consumption and the commencement of hydrogen production was substantially longer $(24 \mathrm{~h}$ later than at $\mathrm{pH}$ 7.0).

Nickel $\left(\mathrm{Ni}^{2+}\right)$ and iron $\left(\mathrm{Fe}^{2+}\right)$ are both essential cofactors in the catalytic sites of a broad range of enzymes (Waldron and Robinson 2009), and both the Ni-Fe $\mathrm{CODH}$ and $\mathrm{Ni}-\mathrm{Fe}$ group 4a hydrogenase that catalyse the WGS are reported to contain both of these co-factors (Mohr et al. 2018a). Thus, the addition of both of these elements to the $P$. thermoglucosidasius growth medium might be expected to have a positive effect on hydrogenogenesis. When doubling the amount of $\mathrm{Fe}^{2+}(0.08 \mathrm{mM}$ $\mathrm{FeSO}_{4} \cdot 7 \mathrm{H}_{2} \mathrm{O}$ ) normally added to mLB medium, there was an evident decrease in the lag phase between oxygen consumption and hydrogen production and the maximum $\mathrm{H}_{2}$ production rate was $8 \%$ higher than at lower concentrations. However, the addition of $\mathrm{NiSO}_{4} \cdot 6 \mathrm{H}_{2} \mathrm{O}$ had a negative impact on both the growth of $P$. thermoglucosidasius DSM 6285, the length of the pre-hydrogenogenic lag phase, $\mathrm{H}_{2}$ yield and maximum $\mathrm{H}_{2}$ production rate. A study of the effects of nickel on $\mathrm{H}_{2}$ production by anaerobic sludge bacteria showed that increasing the nickel concentration from $0.0 \mathrm{mM}$ up to $0.01 \mathrm{mM}$ led to an increase of hydrogen production, while higher nickel concentration had a negative effect on hydrogen production (Wang 
and Wan 2008). Furthermore, the lag phase of hydrogen production could be decreased to $6 \mathrm{~h}$ by using $0.01 \mathrm{mM}$ nickel (Wang and Wan 2008). As such, further fine-tuning of the amount of nickel added may be necessary for improved $P$. thermoglucosidasius hydrogenogenesis.

The current study highlights that WGS catalyzed hydrogenogenesis in $P$. thermoglucosidasius is a finely balanced process with variations in all the tested operational parameters having either a positive or negative impact on $\mathrm{H}_{2}$ yield, maximal (specific) production rates, as well as the time frame of the lag phase preceding hydrogenogenesis and the growth. The optima for each parameter combined in a further experiment resulted in higher production rate compared to set ups in which individual parameters were tested separately. This study can serve as a basis for up-scale fermentations. However, the effects of additional parameters such as the stirrer rate and flow rate of the feed gas inherent to up-scale fermentations will also need to be evaluated.

Hydrogenogenesis via the WGS in P. thermoglucosidasius is a finely balanced process, which is influenced by key operational parameters. While some parameters such as temperature and initial medium $\mathrm{pH}$ reflect the optimum growth conditions for P. thermoglucosidasius others such as the age of the pre-culture and inoculum volume are more complex and may rather indicate the importance of the physiological state of $P$. thermoglucosidasius on its hydrogenogenic capacity. Further investigations, including gene expression analysis and metabolic profiling may shed light on additional factors influencing hydrogen production which, together with additional fine-tuning of operational parameters, can be used to develop up-scale fermentations with a continuous $\mathrm{CO}$ feed for commercial hydrogen production using the facultatively anaerobic thermophilic carboxydotroph P. thermoglucosidasius.

\section{Supplementary information}

Supplementary information accompanies this paper at https://doi. org/10.1186/s13568-019-0931-1.

Additional file 1. Effect of initial gas composition on $\mathrm{H}_{2}$ production. $\mathrm{OD}_{600}$ and gas composition during the cultivation of $P$. thermoglucosidasius DSM 6285 with an initial gas atmosphere of (A) $36 \%$ CO $+64 \%$ air (B) $50 \%$ CO + 50\% air (C) $75 \%$ CO + 25\% air.

Additional file 2. Effect of inoculum preparation on $\mathrm{H}_{2}$ productioninoculum size. $\mathrm{OD}_{600}$ and gas composition during the cultivation of $P$. thermoglucosidasius DSM 6285 with different inoculum sizes of (A) 2\% (B) $10 \%$ and (C) $20 \%$.

Additional file 3. Effect of inoculum preparation on $\mathrm{H}_{2}$ productionincubation time of the 2 nd pre-culture. $\mathrm{OD}_{600}$ and gas composition during the cultivation of $P$. thermog/ucosidasius DSM 6285 with variations in the incubation time of the 2 nd pre-culture: (A) $4 \mathrm{~h}$ (B) $12 \mathrm{~h}$ (C) $24 \mathrm{~h}$.

Additional file 4. Effect of cultivation temperature on $\mathrm{H}_{2}$ production. $\mathrm{OD}_{600}$ and gas composition during the cultivation of $P$. thermog/ucosidasius DSM 6285 with different cultivation temperatures: (A) $50^{\circ} \mathrm{C}$ (B) $55^{\circ} \mathrm{C}$ (C) $60^{\circ} \mathrm{C}$.

Additional file 5. Effect of initial $\mathrm{pH}$ on $\mathrm{H}_{2}$ production. $\mathrm{OD}_{600}$ and gas composition during the cultivation of P. thermog/ucosidasius DSM 6285 with different pH set ups: (A) pH 5.5 (B) pH 7.0 (C) pH 8.5 .

Additional file 6. Effect of Nickel and Iron concentration on $\mathrm{H}_{2}$ production. $\mathrm{OD}_{600}$ and gas composition during the cultivation of P. thermoglucosidasius DSM 6285 with addition of trace elements: (A) $0.3 \mathrm{mM}$ $\mathrm{NiSO}_{4} \cdot 6 \mathrm{H}_{2} \mathrm{O}+0.04 \mathrm{mM} \mathrm{FeSO}{ }_{4} \cdot 7 \mathrm{H}_{2} \mathrm{O}$ and (B) $0.080 \mathrm{mM} \mathrm{FeSO} \cdot 7 \mathrm{H}_{2} \mathrm{O}$ (C) $0.04 \mathrm{mM} \mathrm{FeSO}_{4} \cdot 7 \mathrm{H}_{2} \mathrm{O}$.

\section{Acknowledgements}

Not applicable.

\section{Authors' contributions}

TM designed all experiments and analyzed the data, performed the cultivation with $L B, R G$ und $A H$ the experiments and drafted the manuscript. HA contributed to the experimental design and drafted the manuscript. LB, RG und AH performed the experiments with TM. DC edited the manuscript. PM conceived the experiments and drafted the manuscript. AN contributed to the experimental design and reviewed the manuscript. All authors read and approved the final manuscript.

\section{Funding}

TM was supported by the Federal Ministry of Education and Research (Grant \#031B0180). PDM was funded by the National Research Foundation of South Africa (Grant \# 109137) and HA by Alexander von Humboldt Foundation. We acknowledge support by Deutsche Forschungsgemeinschaft and Open Access Publishing Fund of Karlsruhe Institute of Technology.

\section{Availability of data and materials}

The data supporting the conclusions of this article are included in the article. Data and materials can also be requested from the corresponding author.

\section{Ethics approval and consent to participate}

This article does not contain any studies with animals or human participants performed by any of the authors.

\section{Consent for publication}

Not applicable.

\section{Competing interests}

The authors declare that they have no competing interests.

\section{Author details \\ 1 Section II: Technical Biology, Institute of Process Engineering in Life Science, Karlsruhe Institute of Technology, 76131 Karlsruhe, Germany. ${ }^{2}$ Department of Biochemistry, Genetics and Microbiology, Centre for Microbial Ecology and Genomics, University of Pretoria, Hatfield, Pretoria 0028, South Africa. ${ }^{3}$ School of Molecular \& Cell Biology, Faculty of Science, University of the Wit- watersrand, Johannesburg, South Africa.}

Received: 4 October 2019 Accepted: 11 December 2019 Published online: 23 December 2019

\section{References}

Bertrand RL (2019) Lag phase is a dynamic, organized, adaptive, and evolvable period that prepares bacteria for cell division. J Bacteriol 201 (7):e0069718. https://doi.org/10.1128/JB.00697-18

Bertsch J, Müller V (2015) CO metabolism in the acetogen Acetobacterium woodii. Appl Environ Microbiol 81(17):5949-5956. https://doi. org/10.1128/AEM.01772-15

Can M, Armstrong FA, Ragsdale SW (2014) Structure, function, and mechanism of the nickel metalloenzymes, CO dehydrogenase, and acetyl-CoA synthase. Chem Rev 114(8):4147-4174. https://doi.org/10.1021/cr400461p 
Daniell J, Kopke M, Simpson SD (2012) Commercial biomass syngas fermentation. Energies 5(12):5372-5417. https://doi.org/10.3390/en5125372

Diender M, Stams AJM, Sousa DZ (2015) Pathways and bioenergetics of anaerobic carbon monoxide fermentation. Front Microbiol 6:1275. https ://doi.org/10.3389/fmicb.2015.01275

Gurujeyalakshmi G, Oriel P (1989) Isolation of phenol-degrading Bacillus stearothermophilus and partial characterization of the phenol hydroxylase. Appl Environ Microbiol 55:500-502

Japaar SZ, Kalil MS, Ali E, Anuar N (2011) Effects of age of inoculum, size of inoculum and headspace on hydrogen production using Rhodobacter sphaeroides. J Bacteriol 1:16-23. https://doi.org/10.3923/bj.2011.16.23

Kotay SM, Das D (2007) Microbial hydrogen production with Bacillus coagulans IIT-BT S1n isolated from anaerobic sewage sludge. Bioresour Technol 98:1183-1190. https://doi.org/10.1016/j.biortech.2006.05.009

Mohammadi M, Mohamed AR, Najafpour GD, Younesi H, Uzir MH (2014) Kinetic studies on fermentative production of biofuel from synthesis gas using Clostridium ljungdahlii. Sci World J. https://doi. org/10.1155/2014/910590

Mohr T, Aliyu H, Küchlin R, Polliack S, Zwick M, Neumann A, Cowan D, de Maayer P (2018a) CO-dependent hydrogen production by the facultative anaerobe Parageobacillus thermoglucosidasius. Microb Cell Fact 17:108. https://doi.org/10.1186/s12934-018-0954-3

Mohr T, Aliyu H, Küchlin R, Zwick M, Neumann A, Cowan D, de Maayer P (2018b) Comparative genomic analysis of Parageobacillus thermoglucosidasius strains with distinct hydrogenogenic capacities. BMC Genomics 19:880. https://doi.org/10.1186/s12864-018-5302-9

Nikolaidis P, Poullikkas A (2017) A comparative overview of hydrogen production processes. Renew Sustain Energy Rev 67:597-611. https://doi. org/10.1016/j.abb.2004.08.032

Peters JW, Shut GJ, Boyd ES, Mulder DW, Shepard EM, Broderick JB, King PW, Adams MW (2015) [FeFe]- and [NiFe]-hydrogenase diversity, mechanism, and maturation. Biochim Biophys Acta Mol Cell Res 1853(6):1350-1369. https://doi.org/10.1016/j.bbamcr.2014.11.021

Ramachandran R, Menon EK (1998) An overview of industrial uses of hydrogen. Int J Hydrog Energy 23:593-598
Rostrup-Nielsen JR (1993) Production of synthesis gas. Catal Today 18(4):305324. https://doi.org/10.1016/0920-5861(93)80059-a

Seengenyoung J, Sompong O, Thong TI, Prasetsan P (2011) Effect of inoculum size for biohydrogen production from palm oil mill effluent. In: TIChE international conference, 2011

Sokolova TG, Henstra AM, Sipma J, Parshina SN, Stams AJM, Lebedinsky AV (2009) Diversity and ecophysiological features of thermophilic carboxydotrophic anaerobes. FEMS Microbiol Ecol 68:131-141. https://doi.org/10 .1111/j.1574-6941.2009.00663.x

Sørensen B, Spazzafumo G (2011) Hydrogen and fuel cells. Emerg Technol Appl. https://doi.org/10.1016/C2009-0-63881-2

Suzuki Y, Kishigami T, Inoue K, Mizoguchi Y, Eto N, Takagi M, Abe S (1984) Bacillus thermoglucosidasius sp. nov., a new species of obligately thermophilic bacilli. Syst Appl Microbiol 4(4):487-495. https://doi.org/10.1016/s0723 -2020(83)80006-x

Tirado-Acevedo O, Chinn MS, Grunden AM (2010) Production of biofuels from synthesis gas using microbial catalysts. Adv Appl Microbiol 70:57-92. https://doi.org/10.1016/S0065-2164(10)70002-2

Waldron KJ, Robinson NJ (2009) How do bacterial cells ensure that metalloproteins get the correct metal? Nat Rev Microbiol 6:25-35. https://doi. org/10.1038/nrmicro2057

Wang J, Wan W (2008) Influence of $\mathrm{Ni}^{2+}$ concentration on biohydrogen production. Bioresour Technol 99:8864-8868

Zeigler DR (2001) The genus Geobacillus. Introduction and strain catalog. In: Bacillus Genetic Stock Center, Catalog of Strains, 7th edn, vol 3. The Bacillus Genetic Stock Center, Columbus, pp 20-22. http://bgsc.org/catal ogs.php

\section{Publisher's Note}

Springer Nature remains neutral with regard to jurisdictional claims in published maps and institutional affiliations.

\section{Submit your manuscript to a SpringerOpen ${ }^{\odot}$ journal and benefit from:}

- Convenient online submission

- Rigorous peer review

- Open access: articles freely available online

- High visibility within the field

- Retaining the copyright to your article

Submit your next manuscript at $\boldsymbol{\Delta}$ springeropen.com 